\title{
Sınıf Öğretmenlerinin STEM Eğitimine Yönelik Görüşlerinin Değerlendirilmesi
}

\author{
The Opinions of Elementary Teachers about STEM Education
}

\author{
Mücahit KÖSE ${ }^{\mathrm{a}}$, Reha ATAŞ
}

Öz

Araştırmada sınıf öğretmenlerinin STEM eğitim yaklaşımına yönelik görüşlerini değerlendirmek amaçlanmışıı. Araștırma temel nitel araştırma deseninde gerçekleștirilmiştir. Araștırmanın çalışma grubu olasılığa dayalı olamayan yöntemlerinden amaçı ölçüt örnekli yöntemiyle belirlenmiştir. Araştırmanı çalışma grubunun araştırmanın amacına uygun olarak STEM eğitimi almış yedi sınıf öğretmeni olușturmaktadır. Araștırmacılar tarafından konu ile ilgili yarı yapılandırılmıș görüșme formu tasarlanmıș pilot uygulama ile formda düzenlemeler yapılııştır. Araştırmaya katılan sınıf öğretmenleri ile görüşmeler gerçekleștirilmiş, veriler kaydedilmiş ve içerik analiz yöntemi ile analiz edilmiștir. Araştırmanın sonuçlarına göre sınıf öğretmenleri STEM eğitimini ülkemiz açısından önemli görmekte olup, uygulamalar yapmak için eğitime intiyaç duyduklarını belirtmişlerdir. Şınıf öğretmenleri STEM eğitim uygulamalarında fen bilimleri alanını tercih ettiklerini bunun nedeni olarak diğer disiplinlerde kendilerini yeterli görmediklerini belirtmişlerdir. Öğretmenler STEM eğitim uygulamaları sürecinde materyal temini ve ders süreleri açısından sıkıntı yaşadıklarını ifade etmişler. STEM Eğitimi uygulamalarına özellikle mühendislik disiplinini entegre etmekte zorlandıklarını ve STEM eğitiminin sınıflarda etkili uygulanabilmesi için Millî Eğitim Bakanlığı tarafınca öğretmenlerin eğitimler ile desteklenmeleri gerektiğini belirtmişlerdir.

Anahtar Kelimeler: Öğretmen Eğitimi, STEM Eğitimi, Sınıf Öğretmeni

\begin{abstract}
In this study, the opinions of elementary teachers regarding STEM education approach were examined. The sample of the research consists of seven classroom teachers. The basic qualitative research design was used in the study. A semi-structured interview form was designed by the researchers, and arrangements were made with the pilot application. Interviews were made with the classroom teachers who participated in the research, the data were recorded and analyzed with the descriptive analysis method. According to the results of the research, classroom teachers consider STEM education important for our country and stated that teachers need the education to make practices. Class teachers stated that they preferred the science field in STEM education practices and that they did not consider themselves sufficient in other disciplines. They stated that they had difficulties in terms of material supply and lesson periods during STEM education practices. They have difficulties in integrating especially engineering discipline into STEM Education practices. Teachers thought that the ministry should prepare a plan for STEM education also teachers should be supported on STEM education with the seminars, workshops, and trainings provided by the Ministry of National Education.
\end{abstract}

\author{
Makale Hakkında \\ Tür: Araştırma \\ Geliş Tarihi: 19 Kasım 2020 \\ Kabul Tarihi: 13 Aralık 2020 \\ Yayın Tarihi: 16 Aralık 2020 \\ DOI: $10.31805 /$ acjes.828442 \\ Sorumlu Yazar: \\ Mücahit Köse \\ Alanya Alaattin Keykubat Üniversitesi \\ Antalya/Türkiye. \\ E-posta: mucahit.kose@alanya.edu.tr
}

Keywords: Teacher Education, STEM Education, Elementary Teacher

\section{Önerilen APA Atıf Biçimi / Suggested APA Citation}

Köse, M., \& Ataș, R. (2020). Sınıf öğretmenlerinin stem eğitimine yönelik görüşlerinin değerlendirilmesi. Academy Journal of Educational Sciences, 4(2), 103-110. http://dx.doi.org/10.31805/acjes.828442

aMücahit KÖSE-ORCID: https://orcid.org/0000-0002-1938-6092

Alanya Alaattin Keykubat Unniversitesi, Eğitim Fakültesi, Matematik ve Fen Bilimleri Eğitimi Bölümü, Turkiye. E-posta: mucahit.kose@alanya.edu.tr

Alanya Alaattin Keykubat University. Faculty of Education, Department of Mathematics and Science Education, Antalya/Turkey. E-mail: mucahit.kose@alanya.edu.tr

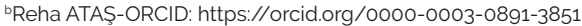

Milli Eğitim Bakanlığı, Antalya/Turkiye. E-posta: rehatas86@gmailcom

Ministry of National Education, Antalya/Turkey. E-mail: rehatas86@gmail.com 


\section{Giriş}

Türk eğitim sistemini; yeni eğitim yaklaşımları, toplumun güncel intiyaçları, uluslararası platformlarda gerçekleştirilen PISA ve TIMMS vb. sınavlar, bilimsel ve teknolojik gelişmelerin yanı sıra Avrupa Birliği ülkeleri ile Amerika Birleşik Devletleri'nin izlediği eğitim politikaları etkilemektedir (Çorlu, Caprora ve Caprora, 2014; Sağlam, Özüdoğru ve Çıray, 2011; Turan, 2005). Türkiye'de fen bilimleri dersi öğretim programlarının yenilenmesi ile birlikte "mühendislik ve girişimcilik becerileri" adı altında STEM eğitimi dikkat çekmektedir. STEM eğitimi 2018 yılında fen bilimleri öğretim programında mühendislik ve girişimcilik becerileri ile fen eğitiminin özel amaçları arasında yer almıştır.

STEM fen (science), teknoloji (technology), mühendislik (engineering), matematik (mathematics) disiplinlerinden oluşan bir eğitim yaklașımıdır (Gonzalez ve Kuenzi, 2012). STEM disiplinleri arasında keskin sınırlar yoktur. STEM; fen, matematik, teknoloji ve mühendislik alanlarının birbiri ile entegre edildiği, bu disiplinlerin günlük yaşamla ilişkilendirilip 21. yüzyıl becerileriyle donatıldığı bir eğitim yaklaşımıdır (Yıldırım, 2016). 21.yüzyıl becerileri öğrenme ve yenilenme, yaşam ve kariyer, bilgi, medya ve teknoloji becerileri olarak sınıflandırılmıștır (Partnership for 21st Century Learning, 2016). 21. yüzyıl becerileri Finlandiya, Belçika, Norveç, Italya, Kanada, Avusturalya gibi ülkelerin eğitim programlarının amaçları arasında yer almaktadır (Anagün, Atalay, Kılıç ve Yaşar, 2016). STEM eğitimi ile problem çözen, eleştirel düşünen, işbirlikli çalışabilen, iletişim kabiliyeti yüksek, yaratıcı, teknoloji okuryazarı bir başka ifadeyle 21. yüzyıl becerilerine sahip bireyler yetiştirmek mümkündür (Morrison, 2006). Dolayısıyla küresel pazarda rekabet gücene ulaşmak isteyen teknolojik ve bilimsel açıdan Dünya'ya liderlik etmek isteyen ülkeler için STEM eğitimi büyük öneme sahiptir (Akgündüz ve diğ.,2015; Karataş, 2017). Nitekim STEM eğitimine ilişkin ABD Başkanı Barack Obama da Amerika ulusal kongresinde Dünya genelinde farklı eğitim programları ile hayata geçirilmeye çalışılan STEM eğitiminin artık ulusal bir misyona dönüştüğünü "Bu bizim neslimizin Sputnik anıdır." sözleri ile belirtmiştir (Bybee, 2013).

STEM eğitiminin ülkemiz için yeni bir yaklaşım olduğunu söylebiliriz. STEM eğitiminde okul öncesinden üniversiteye öğrencilerin sistematik düşünmelerinin desteklenmesi, günlük yaşam problemlerine çözüm üretme becerilerinin kazandırılması hedeflenmektedir (Bybee, 2013). STEM eğitiminin uygulanmasında farklı öğretim yöntemlerine başvurulmaktadır. Bu yöntemlerden ilki STEM disiplinlerinin öğrencilere birbirinden bağımsız olarak verilmesidir. Ikincisi STEM disiplinlerinden ikisinin vurgulandığı STEM olarak adlandırılan yöntemdir. Üçüncüsü STEM disiplinlerinden herhangi birinin üç alana entegre edilmesidir. Son olarak ise STEM disiplinlerinin her birinin kullanılarak diğer alanlara entegre edilmesi yoludur (Dugger, 2010). Öğretmenlerin STEM eğitimini gerçekleştirebilmeleri için farklı öğretim yöntemleri izlemeleri dışında bazı niteliklere de sahip olmaları intiyaçtır (Benuzzi, 2015; Stohlman, Moore ve Roehring, 2012. Stohlman, Moore ve Roehring (2012)' e göre bu nitelikler; pedagoji bilgisi, alan bilgisi, 21. yüzyıl becerileri bilgisi ve entegrasyon bilgisidir. STEM eğitimcilerinin sahip oldukları bilgileri uygulayabilmesi program entegrasyonu kavramını ortaya çıkarmıştır (Bozkurt-Altan, Yamak ve Kırıkkaya, 2016). Puzzle parçalarının birleştirilmesine benzetilen program entegrasyonu disiplinlerin birbiri ile uygun şekilde kaynaştırılmasını ve etkili STEM derslerinin gerçekleştirilmesini sağlamaktadır (Drake ve Burns, 2004; Mathison ve Freeman, 1998).

STEM eğitiminin istenilen amaçlarına ulașmasında programın uygulayıcıları olan öğretmenlerin etkisi yadsınamaz. Fen, matematik, teknoloji ve mühendislik alanlarına ilgi duyan bireylerin yetişmesinde öğretmenlerin etkili STEM eğitimi uygulamaları önemlidir (Akgündüz ve diğ., 2015). Öğretmenler, öğretim programının uygulayıcıları olarak programda yer alan hedeflerin gerçekleştirilmesinde başrol görevini üstlenmektedir (Kaya, 2019). Öğretmenlerin Öğretim programın amaçlarının ve öğelerinin farkında olması STEM eğitiminin hayata geçirilmesinde sınıf atmosferi, öğrenci sayısı gibi değişkenleri göz önünde bulundurarak profesyonel uygulamalar gerçekleștirebilmesi fen öğretim programlarının hedeflerine ulaşması için önemlidir. Özellikle öğretmenlerin STEM eğitimi uygulamaları gerçekleştirmeleri, gerçekleştirdikleri uygulamaları değerlendirmeleri ve süreçte yaşadıkları aksaklıkları tespit etmeleri STEM kültürü oluşmasını katkı sağlayacaktır (Gülpınar, 2019). Alan yazın incelendiğinde STEM eğitimi uygulamalarının öğrenci akademik başarısı, tutumu, bilimsel yaratıcıııkları ve kariyer bilinçlerine etkilerini incelmeye yönelik araștırmalar (Daymaz, 2019; Kağnıcı, 2019; Kavacık, 2019; Kurtuluş, 2019; Çengel, Alkan ve Yıldız, 2019) mevcuttur. Bu araştırmaların yanı sıra fen bilimleri öğretmen adaylarının STEM eğitimi etkinlikleri olușturmaları ve STEM eğitiminin ülkemizde uygulanabilirliğine yönelik görüşlerinin incelendiği araştırmalar (Kaya, 2019; Poyraz, 2018; Şahin, 2019) da literatürde yer almaktadır. Literatürde yer alan araştırmaların büyük oranda fen öğretmen ve öğretmen adaylarıyla gerçekleştirildiği görülmektedir.

Sınıf öğretmeni adaylarıyla gerçekleștirilen araştırmada Yıldırım ve Türk (2018) sınıf öğretmeni adaylarına yönelik eğitim programı tasarlamış, öğretmen adaylarına STEM eğitimleri vermiş, öğretmen adaylarının sınıf uygulamaları sonrası görüşlerini belirlemişlerdir. ilgili alan yazında sınıf öğretmenlerinin Milli Eğitim Bakanlığının (MEB) Öğretim programı kapsamında STEM uygulamalarını, uygulama sürecinde yaşadıkları problemleri ve süreç içerisindeki deneyimlerini inceleyen herhangi bir araştırmaya rastlanılmamıştır.

STEM eğitimi, küresel ekonomi açısından gelişmekte olan Türkiye için kritik öneme sahiptir (Çorlu, 2014). TÜSIAD (2017) raporuna göre STEM alanlarının eğitim ve iş gücünde öneminin fark edilmesi gereklidir. Bu bağlamda STEM eğitiminin uygulanması, STEM disiplinlerine ilişkin öğretmen görüşlerinin alınması, uygulama sürecinde yaşanan problemlerin tespit edilmesi önemlidir. Araştırma sonuçlarının sınıf öğretmenlerinin STEM eğitim yaklaşımı uygulamadaki problemleri ortaya çıkarması, STEM eğitimi ile ilgili araştırmacılara kaynaklık etmesi ve Bu bağlamda araștırmanın ilgili literature katkı sunacağı düșünülmektedir. Araștırmanın amacı, sınıf öğretmenlerinin STEM Eğitimine yönelik görüşlerini değerlendirmektir. Bu amaç kapsamında araștırmanın problem cümlesi; Sınıf öğretmenlerinin STEM eğitimine yönelik görüşleri nelerdir? olarak belirlenmiştir

\section{Yöntem}

\section{Araștırma Modeli}

Bu araştırmada STEM eğitimine yönelik sınıf öğretmenlerinin görüşleri belirlenmiştir. Bu kapsamda araştırma temel nitel araştırma desenindedir. Nitel araştırmalarda birçok değişkene bağlı olarak doğal çevreden elde edilen verilerden yararlanılır. Araştırma bağlamındaki anlamın ortaya çıkartılması amacıyla veri toplarken yorumlarken duyarlı bir ölçme aracı kullanıır. Nitel araştırmalar insanların dünyalarını nasıl inşa ettikleri, deneyimleri nasıl algıladıkları, hangi anlama yükledikleriyle ilgilenir (Merriam, 2009). Araștırmada katılımcıların deneyimlerinin, algıladıklarının, konu ile ilgili yükledikleri anlamların ortaya çıkarılması amaçlanmıştır. 


\section{Çalışma Grubu}

Araştırmanın çalışma grubuna dâhil olan sını öğretmenleri olasıı̆̆a dayalı olmayan örnekleme yöntemlerinden amaçlı uygun ölçüt örnekleme yöntemiyle belirlenmiştir. Araştırmanın örneklemini oluş̧turan yedi sınıf öğretmeni de Millî Eğitim Bakanlığı'na bağlı yedi farklı devlet okulunda öğretmenlik yapmaktadır. Araştırmanın amacı doğrultusunda öğretmenler STEM eğitimini bu eğitimi veren kurumlardan yüz yüze eğitim yoluyla almış ve eğitimleri sonrasında en az 10 ders saati sınıflarında STEM uygulamaları gerçekleştirmişler. Çalışma grubunda yer alan öğretmenlere ilişkin mesleki kıdem ve çalıştığı Okulların bulunduğu yerleșim birimleri araștırma da değișken olarak alınmamıș bilgi vermek amacıyla belirtilmiştir. Araştırmaya katılan sınıf öğretmenlerine ilişkin nitelikler Tablo 1'de sunulmuştur.

Tablo 1. Çalışma Grubu Özellikleri

\begin{tabular}{|c|c|c|c|c|}
\hline $\begin{array}{c}\text { Sınıf } \\
\text { Öğretmeni }\end{array}$ & Branş & Kıdem & $\begin{array}{l}\text { STEM eğitimi } \\
\text { alıp-almama } \\
\text { durumu }\end{array}$ & $\begin{array}{l}\text { Çalıştığı okulun } \\
\text { bulunduğu } \\
\text { yerleşim birimi }\end{array}$ \\
\hline Ö1 & \multirow{7}{*}{ 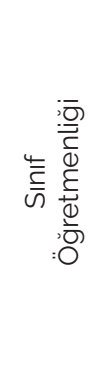 } & 21 & $\sqrt{ }$ & İl-ilçe Merkezi \\
\hline Ö2 & & 23 & $\sqrt{ }$ & İl-ilçe merkezi \\
\hline Ö3 & & 20 & $\sqrt{ }$ & Il-ilçe Merkezi \\
\hline Ö4 & & 12 & $\sqrt{ }$ & İl-ilçe merkezi \\
\hline Ö5 & & 10 & $\sqrt{ }$ & Köy-kasaba \\
\hline Ö6 & & 6 & $\sqrt{ }$ & Köy-kasaba \\
\hline Ö7 & & 5 & $\sqrt{ }$ & Köy-kasaba \\
\hline
\end{tabular}

Veri Toplama Araçları

Araştırmada sınıf öğretmenlerinin STEM eğitimi uygulamalarına yönelik görüşlerini belirlemek amacıyla araştırmacılar tarafından yarı yapılandırılmış görüşme formu oluşturulmuş ve bu form rehberliğinde görüşmeler gerçekleştirilmiştir.

\section{Yarı yapılandırılmış öğretmen görüşme formu}

Araştırmada görüşme formu alanyazın taraması yapılarak araştırmanın amacına hizmet eden soru havuzu oluşturulmuştur. Yarı yapılandırılmış görüşme sorularının sıralanışı, araştırmanın amacına hizmet eden soruların açıkığı, kapsamı, öğretmenler tarafından anlaşılırığı açısından uzman görüşleri değerlendirilmiş, deneme uygulaması yapılmıştır. Görüşme soruları araştırmanın alt problem cümleleri doğrultusunda STEM eğitiminin avantajları, uygulamalarda yaşanan sıkıntılar ve öğretmenlerin STEM hakkındaki görüşlerini belirlemeye yönelik olarak hazırlanmıştır. Görüşme formu ile yapılan deneme uygulaması sonrası yarı yapılandırılmış görüşme formundan herhangi bir soru çıkarılmamış olup sorularda düzenlemeler yapılmıştır. Görüşme formu altı sorudan oluşmaktadır. Öğretmenlerle görüşmeler öncesi iletişime geçilerek ortak zaman belirlenmiştir. Görüşme öncesi öğretmenlere görüşmenin kapsamı araştırmanın amacı araştırmacının rolü görüşmelerin gizliliği gibi konularda bilgiler verilmiştir. Gönüllü katılımın olması gerektiği ifade edilerek öğretmenlerin bilgilendirilmiş katıım onayları alınarak ve gerçekleştirilen görüşmeler kayıt altına alınmıştır. Her bir öğretmen ile yaklaşık 40 dakikalık görüşmeler gerçekleştirilmiştir. Araştırmanın geçerlilik ve güvenirliğinin sağlanması açısından veri toplama aracının hazırlanmasında uzman görüşü alınmıştır. Görüşmelerden önce öğretmenlerin bilgilendirilmiş onamı alınmıştır. Görüșme öncesi görüșmenin amacl, görüşmelerin kayıt altına alınacağı, öğretmenlerin kimliklerinin gizli tutulacağı belirtilmişstir. Görüşmelerden elde edilen kayıtlarda değişiklik yapılmadan doğrudan alıntılar yapılmış, elde edilen veriler katılımcılara teyit ettirilmiştir

\section{Verilerin Analizi}

Araştırmada verilerin analizi için içerik analizi kullanılmıştır İçerik analizinde temel amaç toplanan verileri açıklayabilecek kavramlara ve ilișkilere ulașmaktır (Yıldırım ve Șimșek, 2016). İçerik analizinde ön hazırlık aşaması ile araştırmacı tarafından veriler aralıklı tekrarlar ile okunmuștur. Kodların oluşturulması aşamasında araştırmacı cümle ve sözcük öbeklerinin altını çizerek kodlara ulaşmıştır. Temalara ulaşma aşamasında araştırmacı tarafından yapılan kodlamaların içsel benzeşiklik dısssal heterojenliğe ulaşması sağlanarak temalar belirlenmiştir. Verilerin örgütlenmesi aşamasında araştırmacı tarafından Microsoft Excel programına temalar, kodlar, katılımcıların zıt ifadeleri eklenmiştir. Verilerin örgütlenmesi aşamasında alıntılar Excel'de mevcut olan kopyala yapıștır işlevi ile veri üzerinde oynama yapılmadan rapora dahil edilmiştir. Tema ve kategoriler birleştirilerek bulgularda tablolaştırılmıştır. Araştırmacı tarafından oluşturulan birbirine benzer yakınlık bulunan kodlar ve temalar uzman tarafından tekrar analiz edilmiştir. Miles ve Hubermann'ın (1994) uyum uyuşum yüzdesi hesaplanmış \%91 bulunmuştur. Kodlama işleminin güvenirliği sağlanmıştır.

\section{Araştırmanın Etik İin Bilgileri}

Yapılan bu çalışmada "Yükseköğretim Kurumları Bilimsel Araştırma ve Yayın Etiği Yönergesi" kapsamında uyulması belirtilen tüm kurallara uyulmuștur. Yönergenin ikinci bölümü olan "Bilimsel Araştırma ve Yayın Etiğine Aykırı Eylemler" başlığı altında belirtilen eylemlerden hiçbiri gerçekleştirilmemiştir. Araştırmada katılımcı öğretmenler bilgilendirilmiş gönüllü görüşme formalarını imzalayarak araştırmaya katılmışlar ve öğretmenlerle görüşmeler gerçekleştirilmiştir. Araştırmanın etik ile ilgili hususlarında tüm sorumluluk yazarlara aittir

\section{Etik kurul izin bilgileri}

Etik Değerlendirmeyi Yapan Kurul Adı: Bartın Üniversitesi Sosyal ve Beşeri Bilimler Etik kurulu

Etik Değerlendirme Kararının Tarihi:5.11.2020

Etik Değerlendirme Belgesi Sayı Numarası:2020-SBB-0232

\section{Bulgular}

Sınıf öğretmenlerin görüşmelerde verdikleri yanıtlar analiz edilerek STEM eğitimin avantajları, STEM eğitiminin Dezavantajları, STEM ders uygulamaları ve STEM eğitimi temaları altında alt tema ve kodlar oluşturulmuştur.

\section{STEM Eğitiminin Avantajları}

Araştırmada öğretmenlerden STEM eğitimi uygulamalarının sağladığı avantajlara ilişkin bilgiler elde edilmiştir. Öğretmenler öğrenci açısından dikkat çekici olması, derse olan ilgiyi arttırması, dersin eğlenceli geçmesi sebebiyle öğrencilerin aktif katıımına katkı sağladığını görüşmelerde belirtmiştir. Öğretmenlerin ifadeleri doğrultusunda STEM eğitiminin avantajları temasına ait alt tema ve kodlar Tablo 2'de sunulmuş̧tur.

Araştırmada STEM uygulamalarını derslerinde sürdüren öğretmenlerden Ö3 STEM ile derslerin eğlenceli geçtiğini, derslerdeki uygulamaların öğrencilerin ilgisini çektiğini belirtmiştir. Öğretmenlerden Ö2 öğrencinin dikkatini çeken STEM uygulamalarının öğrencilerin aktif katıımını sağladığını belirtmiştir. 
Tablo 2. STEM Eğitiminin Avantajları

\begin{tabular}{|c|c|c|}
\hline \multirow{3}{*}{ 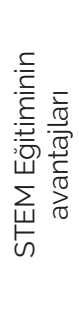 } & Alt tema & Kodlar \\
\hline & Öğrenci açısından & $\begin{array}{c}\text { Öğrenci ilgisini çekme } \\
\text { Öğrenci aktif katılımı } \\
\text { Derslerin eğlenceli olması }\end{array}$ \\
\hline & Öğretmen açısından & $\begin{array}{c}\text { 21. yüzyıl becerileri } \\
\text { Somutlaştırma imkânı } \\
\text { Tam öğrenme sağlaması } \\
\text { Sınıf öğretmenliğinin avantajı }\end{array}$ \\
\hline
\end{tabular}

"...daha çok çocukların ilgisini çekiyor, mükemmeliyetçilik aramadığı için bir gerginlik yok şınıf açısından da öğretmen açısından da ben çok eğlenceli buldum." (Ö3)

"Avantajları bir kere derse katılım olduğunda çok sıkıntı yaşamıyorsunuz ders süresince, başka branş öğretmenlerini işin içine katma gibi bir avantajımı var bu yolla STEM yaygınlaştırabilirsiniz. Dikkat çekiyor öğrencinin katılımı sağlıyor." (Ö2)

Öğretmenlerden Ö4 ise konuyla ilgili diğerlerinde farklı olarak özellikle fen ve matematik alanlarında öğrencilerin zayıf olduğunu bu açıdan STEM'in aktif katııma katkı sağladığını belirtmiştir.

"STEM fen ve bilimi öğrencilere eğlenceli hale getirdiği için ögrenci ilgisini arttıran bir şey yani ülkemizin de bu konuya intiyacı olduğunu düşünüyorum. Fen matematik alanlarında genel anlamda çocuklar zayıf bu derslerde katıımı sağlaması acısından çok güzel üstelik derslerde eğlencelidir." (Ö4)

Araştırmada öğretmenler STEM eğitim uygulamalarının öğretmenlerin programın amaçlarını gerçekleştirme açısından katkı sağladığını, özellikle sınıf öğretmenliğinin STEM uygulamalarında diğer branş öğretmenlerine göre avantajlı konumda olduğunu belirtmişlerdir. Öğretmenlerden Ö2, fen bilimlerindeki kavramların somutlaștırılmasında STEM'in etkili olduğu yönünde görüşlerini belirtirken Ö1, 21. yüzyıl becerilerinin kazandırılmasında STEM'e vurgu yapmıştır. Ö3 ise sınıf öğretmenliğinin diğer branşlara göre STEM konusunda avantajlı olduğunu belirtmiştir.

"Birde STEM ile ilgili yapılan çalışmaları sınıf öğretmeni olduğunuzdan dolayı birçok alanı kapsadığını işte fen matematik olanların hepsine bize öğrettiğimiz için çok iyi oldu bizim için derslerin hepsine girdiğimiz için avantajlıyı. Iște bu durum da sınıf öğretmeni olmamızdan kaynaklı örneğin diğer öğretmenleri görüyoruz brans öğretmenlerini mesela bir edebiyat ögretmeni kimya öğretmeni Edebiyat öğretmeni fen bilgisi ile alakalı çok az bilgiye sahiptir mesela kimya öğretmeni edebiyatla ilgili çok fazla bilgi sahibi değildir ama bizim şöyle bir artımız oluyor. Çok derinlemesine bilgi vermemize gerek yok." (Ö3)

"Onları sunduğumuz bilgilerde en azından sadece bilgi vermeye çalıştığınız etkinliklere baktığınız zaman somut bir şeyler ortaya çıkardıkları zaman bilgileri daha kolay öğrendiğini gördük. Yani kavramların somutlaşmasında etkili." (O2)

"Öğrencilerimiz Normalde programın kazanımların tamamını kazanıyorlar zaten Bir de öğrencilerin 21 yüzyıl becerileri temel bilimsel süreç becerilerini kazanmalarını hedefliyorum. Güzel sonuçlar elde ettiğimiz ile söyleyebilirim. O nedenle etkilidir." (Ö1)

Araştırmada Ö4, diğer öğretmenlerden farklı olarak STEM'in öğrencilerin tam öğrenmesini sağladığını öğrencinin hedeflenen kazanımlara ulaşmadan ürün oluşturmadığını dolayısıyla tam öğrenmenin sağlanması açısından STEM'in önemli olduğunu belirtmiştir.
"Farklı dersler isin icinde olunca öğrenci eksik bilgide kalmıyor lazım konu seçimi çok iyi yapılması lazım. Doğru kazanım seçildiğinde öğrenci adım adım öğreniyor ve tam öğrenmesini sağlıyor diyebilirim. Sonuca baktığımda öğrencilerimin hepsinin tam anlamıla öğrenip konuyu geçtiğimizi gördüm." (Ö4)

\section{STEM Eğitiminin Dezavantajları}

STEM eğitiminin dezavantajları teması kapsamında öğretmenlerden çevresel ve uygulamadaki etkenler alt temaları kapsamında bilgiler elde edilmiștir. Öğretmenlerin ifadeleri doğrultusunda STEM eğitimi uygulamaları esnasında öğretmenlerin karşılaștıkları zorluklar STEM eğitiminin dezavantajları olarak temalaştırılmıştır. STEM Eğitiminin dezavantajları temasına ait alt tema ve kodlar Tablo 3'te sunulmuştur.

Tablo 3. STEM Eğitiminin Dezavantajları

\begin{tabular}{|c|c|c|}
\hline \multirow{3}{*}{ 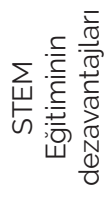 } & Alt tema & Kodlar \\
\hline & Çevresel etkenler & $\begin{array}{l}\text { Süre yetersizliği } \\
\text { Materyal intiyacı }\end{array}$ \\
\hline & $\begin{array}{l}\text { Uygulamadaki } \\
\text { etkenler }\end{array}$ & $\begin{array}{c}\text { Kalabalık sınıfta uygulama güçlüğü } \\
\text { Kendini yetersiz görme }\end{array}$ \\
\hline
\end{tabular}

Araștırmada öğretmenlerden STEM uygulamalarında süre, materyal intiyacı gibi çevresel dezavantajların söz konusu olduğu bunların yanı sıra öğretmenlerin kalabalık sınıflarda uygulama yapmakta zorlandıkları öğrencilere rehberlik etme noktasında yetişemedikleri bulgularına ulaşılmıştır. Öğretmenlerden O4, STEM uygulamaları için sürenin yetersizliğini belirtirken Ö5, malzeme ihtiyacını öğretmenin karşıladığını atık materyaller ile uygulamalar yapabildiklerini kodlama malzemelerinin oldukça pahalı olduğunu ifade etmiştir

"Uygulama sürecinde şu anlamda zorluk yaşadım. Tahmin ettiğim süre ile ortaya çıkan süre biraz farklı oldu. Iște ben bir düşündüğüm süre iki ders üç ders iken ortaya çıkan süre çok daha uzun oldu." (Ö4)

"...STEM için ucuz atık materyal kullanıyoruz. Ama aldığımız kursta kodlama malzemeleri falan da vardır. Açıkçası onları da öğrencilere göstermek isterim. Fakat malzemeleri almamız mümkün değil."(Ö5)

Öğretmenlerden Ö5 ise diğer öğretmenlerden farklı olarak STEM'in malzeme intiyaçları karşılanmadan kırsal bölgelerde uygulanamayacağına ilişkin görüş bildirmiştir.

"Kendim uygulama yapmak için manavdan bir şeyler aldım. Ancak bu şekilde tam uyguladım da diyemiyorum. Bunun kodlaması var, robotiği var açıkçası bu noktada iş parayla alakalı bunlar olmadan ileri seviyede uygulamalar imkânsız." (Ö5)

Öğretmenlerden Ö4STEM eğitimini uygulamada öğrencilerle bire bir etkileşime girmenin zor olduğunu zaman zaman yetișemediğini ifade ederken, Ö1 kalabalık sınıflarda STEM uygulamalarının kaosa neden olabileceğini belirtmiştir.

"Tek başıma olmam gruplara ayırdığımda o gruptan o gruba sorularına hani en büyük sıkıntı artık materyalleri yapıștırmada biliyorsunuz ki çok iyi tutmuyor. Silikon kullanmamı gerekiyor. Silikon tabancasını da vermeye korkuyorum o yüzden ona yetișmekte tek bașıma olduğum zaman Tek bir onda zorluk yaşıyorum yanlarında olamamak hani en azından yanında bir yardımcı olsa ya da birkaç kişi olmuş olsa herkes başında durur çocukların ihtiyacı anında yardımcı olabilir." (Ö4)

"Tek bașımıza sınıfta kaos ortamı olduğu da oldu. Çünkü sınıf 35 kişi gürültü oldu malzeme kırıldı bu tür şeyler de uygulamayı zorlaştırıyor. Uygulanması lazım ama zorlukları var diyebilirim" (Ö1) 


\section{STEM Ders Uygulamaları}

Araştırmada öğretmenlerin STEM uygulamalarında kullandıkları yöntemler, ölçme değerlendirme teknikleri, kullanılan materyal ve beklentilerine ilişkin bilgiler elde edilmiştir. Öğretmenlerin yanıtları doğrultusunda STEM ders uygulama teması kapsamında ders içi materyal, öğretim yöntemi, ölçme değerlendirme, öğretmen beklentileri alt temaları ve kodları Tablo 4'te sunulmuştur.

Tablo 4. STEM Eğitiminin Dezavantajları

\begin{tabular}{|c|c|c|}
\hline \multirow{5}{*}{ 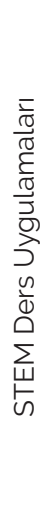 } & Alt tema & Kodlar \\
\hline & Ders içi materyal & $\begin{array}{c}\text { Video materyalleri } \\
\text { Öğretmenin materyal sağlaması }\end{array}$ \\
\hline & Eğitim durumları & $\begin{array}{l}\text { Beyin fırtınası yöntemi } \\
\text { Grup çalışması } \\
\text { İş birlikli çalışma }\end{array}$ \\
\hline & $\begin{array}{c}\text { Ölçme } \\
\text { değerlendirme }\end{array}$ & $\begin{array}{c}\text { Probleme yönlendirme } \\
\text { Öğretmen rehberliği } \\
\text { STEM uygulamasının değerlendirilmesi } \\
\text { Kazanımlara ulaşma }\end{array}$ \\
\hline & $\begin{array}{l}\text { Öğretmen } \\
\text { beklentileri }\end{array}$ & $\begin{array}{c}\text { Öğretmen iş birliği } \\
\text { STEM eğitimi alma } \\
\text { Okul tarafından uygulanması }\end{array}$ \\
\hline
\end{tabular}

Araştırmada öğretmenler; STEM disiplinlerini uygulamada video materyallerden faydalandıklarını, kendilerinin materyal temin etmek durumunda kaldıklarını, beyin fırtınası yöntemi ile öğrencilerin aktif katıımını sağladıklarını, öğrencilere rehberlik ederek uygulamaları gerçekleștirdiklerini belirtmişlerdir. Öğretmenlerden Ö3, öğrencilere videolar ile konuya yönelik dikkat çektiğini belirtmiştir. Ö7 ise STEM uygulamalarını öğrencilerle birlikte değerlendirdiklerini böylece uygulamalarda aksayan yönleri tespit ederek gelişim sağladıklarını belirtmiştir.

"Öncelikle çocuklara konu ile ilgili hikâyeler, videolar, belgeseller kullanarak ya da kısa süreli olarak anlayacakları şekilde resimlerle bilgiler verdim. Daha sonra çocukları problem cümlesine yönlendirmeye çalışım oradan bir problem durumu cıkarmamiz gerekiyordu bunun sonucunda problem durumunu söyledim. Bunun sonucunda beyin firtınası yaparak konuşmalarını sağladım." (Ö̈)

"Değerlendirme çalışmalarını öğrencilerle yaptık, nasıl yaptılar test ettik. Bazı durumları guruplarında neler yaptıkları ve yapamadıkları hakkında konuşuyorduk Bireysel yaptıklarında da birebir neden yaptığını, niçin yaptığını yine her defasında cocukların anlatmasını sağladık değerlendirmeyi de bu şekilde yaptık. Böylece giderek geliştik diyebilirim" (Ö7)

Öğretmenler STEM eğitimini uygulayabilmek için eğitim aldıklarını ancak bu eğitimlerin maliyetini kendileri karşıladıklarını bu noktada Milli Eğitim Bakanlığı'ıın etkili olması gerektiğini belirtmișlerdir. Öğretmenlerden Ö3, özel bir kurumdan STEM eğitimi aldığını ve eğitim almadan uygulamaların yapılamayacağına işaret ederken; Ö4, STEM eğitiminin uygulamalarına katkı sağladığını belirtmiştir.

"Bu eğitimler olmadan benim fikrim yoktu. Kendim okumuş olsam bile bu kadar etkinlik önerileri falan vermeleri iyi oldu yoksa zorlanırdım. Ondan STEM yapmak isteyenlerin eğitim alması şart diye düşünüyorum. Milli Eğitimin bu konuda öğretmenleri desteklemesi gerekli her öğretmen bu eğitimleri karşılayamaz:" (Ö3)

"Eğitim olmadan olmazdı da çünkü kodlama da öğrettiler ama biz kısa bir eğitim aldık yine olsa keşke çünkü Fen'in her konusunda da uygulamaları yapamam gibi geldi. Eğitim olmasaydı yapamazdım bu tür eğitimlerden tekrar da almayı düşünüyorum." (Ö4)
Öğretmenlerden Ö7 ise diğerlerinden farklı olarak STEM'in önemli olduğunu bütün derslerin entegre olmasını sağlaması açısından uygulanması gerektiğini ifade etmiştir.

"Bütün dersleri birbiri ile ilişkilendirebiliyor. Öğrencinin farklı derste anlamadığı konuyu bașka bir disiplinle kavratabiliyorsunuz. Çünkü STEM bu derslerin birbiri içine entegre olması bu nedenle önemli olduğunu düşünüyorum. "(Ö7)

\section{STEM Eğitimi}

ÖğretmenlerinSTEMeğitimineilişkingörüşleridoğrultusunda STEM eğitimi teması kapsamında STEM disiplinleri ve STEM eğitiminin önemi alt temaları oluşturulmuş ve Tablo 5 'te sunulmuştur.

Tablo 5. STEM Eğitimi

\begin{tabular}{|c|c|c|}
\hline \multirow{3}{*}{ 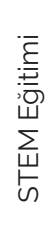 } & Alt tema & Kodlar \\
\hline & STEM disiplinleri & $\begin{array}{l}\text { Mühendislik disiplini } \\
\text { Fen bilimleri disiplini } \\
\text { Fen bilimleri ile uyum }\end{array}$ \\
\hline & STEM eğitimi önemi & $\begin{array}{l}\text { STEM eğitimi gerekliliğ } \\
\text { STEM eğitiminin katkısı }\end{array}$ \\
\hline
\end{tabular}

Araştırmaya katılan öğretmenler STEM eğitimindeki disiplinlerden fen bilimleri disiplininde uygulamaları yaptıklarını mühendislik dișiplini açısından yetersiz olduklarını ifade etmişlerdir. Öğretmenlerden Ö2 ve Ö4 aldıkları eğitimler sayesinde STEM eğitim uygulamalarını gerçekleştirdiklerini daha önceki denemelerinde başarısız olduklarını dolayısıyla eğitim almadan bir öğretmenin STEM eğitimini uygulayabilmesinin mümkün olmadığını eğitim almanın gerekli olduğunu belirtmişlerdir.
"... Eğitim almadan STEM uygulamak çok zor daha önce branşcı arkadașlardan yardım alarak denedim, Youtube videolarından faydalandım. Ancak sinif uygulamalarında başarısız oldum. Issin uzmanından ders eğitim almadan sınıfta yapmak zor oluyor." (Ö2)
"...Bu eğitimler olmadan benim fikrim yoktu. Kendim okumuş olsam bile bu kadar etkinlik önerileri falan vermeleri iyi oldu yoksa zorlanırdım. Ondan STEM yapmak isteyenler eğitim alması şart diye düşünüyorum." (Ö4)

Biçiminde Ö2 ve Ö4 görüșlerini bildirirken Ö6, fen bilimleri ile STEM eğitiminin uygulanabilir olduğunu kendisinin de derslerinde sık sık fen bilimleri dersi üzerinden uygulamalarda bulunduğunu ifade etmiştir. Ö4 ve Ö6 ise diğer disiplinler ile de STEM'in uygulanabileceğini ancak mühendislik disiplini açısından uygulamalarda zorlandığını zaman zaman yardım aldığını belirtmiștir. Ö2 ise STEM uygulamalarında STEM'e uygun kazanımları belirlediğini ve bu kazanımlar doğrultusunda derslerinde uygulamalar yaptığını belirtmiştir.

“... Ondan sonra fen konusunda daha çok fen ağırlıklı oluyor çalışmalar matematiği de içine koyuyoruz ama daha çok fen ağırlıklı." (Ö6)

"Söyle ben fen ve matematik olarak genelde uygulama yaptım. Mühendislik konusunda çok bir bilgim yok. Arkadașlarla birbirimize danıştığımız zamanlar oldu. Mühendislik ile branș olarak alakamız olmadığı için zorlandık." (Ö4)

"Kendimimühendislikveteknolojialanındayeterligörmüyorum. Fen bilimleri zaten hayatın içinde olan bir ders ürün olușturma açısından yeterli bilgiye sahip olduğum için fen derslerini daha çok STEM uygulamalarında tercih ediyorum." (Ö6) 


\begin{abstract}
"...̈nce kazanımlara hayat bilgisi matematik Fen bilgisi kazanımlarına dikkat ederek günlük yaşamdan bir problem içermesine onun dışında mühendislik becerilerini entegre edebileceğimize, Entegre edebileceğimiz bir kazanım olmasına dikkat ettik bir de çocukların seviyesine uygun olmasına dikkat ederek, ilk etapta bunlarla başladıktan sonra gerisi geldi zaten." (Ö2)
\end{abstract}

\section{Tartışma, Sonuç ve Öneriler}

Araştırmada STEM Eğitimi almış sınıf öğretmenlerinin STEM Eğitimi uygulamalarına yönelik görüşleri incelenmiştir. Öğretmenlerin görüşlerinden STEM eğitimi uygulamalarının öğrencilerin ilgilerini çekme, derse aktif katıımlarını sağlama, derslerin eğlenceli hale gelmesini sağladığı belirlenmiștir. Öğretmenlerce STEM eğitiminin öğrencilere 21. yüzyıl becerilerini kazandırmada etkili olduğu, teorik bilgilerin somutlaştırılmasında, öğrencilerin tam öğrenmenin sağlanmasında önemli olduğu ifade edilirken ve sınıf öğretmenliğinin branş olarak uygulamalar için bir avantaj olduğu sonucuna ulaşılmıştır. Bu sonuçlarla benzer olarak Eroğlu ve Bektaş (2016)'da STEM eğitimine ilişkin fen öğretmen görüșlerini değerlendirdikleri araștırmalarında STEM'in öğrenci aktif katılımını sağladığı bu durumun motivasyon ve ilgiyi arttırdığı sonucuna ulaşmışlardır. Başpınar ve Hacıoğlu (2020) ise bir sınıf öğretmeni ile STEM uygulamaları üzerine gerçekleştirdikleri araştırmalarında STEM'in öğretmen açısından avantajlar sağladığını öğrencilere 21. Yüzyıl becerilerinin kazandırılmasında oldukça etkili olduğunu belirtmişlerdir. Özellikle STEM eğitimi ile öğrencilerin ürün tasarlayıp yaratıcılıklarını ortaya çıkarmaları ve 21. Yüzyıl becerilerini kazanmalarının mümkün olacağını ifade eden çalıșmalarda (Küçük ve Șișman, 2017: Yamak, Bulut ve Dündar, 2014; Oliverez, 2012) STEM'in katkısını vurgulamaktadır.

STEM eğitiminin avantajları olduğu kadar dezavantajlarının da olduğu araştırmada öğretmenler tarafından ifade edilmiştir. Söz konusu dezavantajlardan özellikle malzeme intiyacı ve süre yetersizliği, kalabalık sınıflarda uygulamanın zor olması ve öğretmende STEM eğitimine iyi düzeyde yeterlilik gerektirdiği araştırmada ön plana çıkmıştır. Öğretmenlerin ders sürelerinin sınırlı olması sebebiyle uygulamaların hazırlanan ders planlamalarının üzerinde daha uzun süre devam ettirdikleri sonuçlarına ulașılmıștır. Araștırmanın sonuçlarıyla benzer paralellikte Siew, Amir ve Chong (2015) STEM uygulamalarında en büyük zorluğun zaman sıkıntısı olduğunu belirtmiștir. Araștırmada öğretmenlerin mevcut malzemeler ile uygulamaları sürdürdükleri ancak etkili STEM uygulamaları için kodlama setleri gibi maliyet gerektiren malzemelere intiyaç duydukları belirlenmiştir. Oysaki Stohlman, Moore ve Roehring (2012) STEM eğitiminde basit deney kitleri ve yalnızca tahtanın dahi kullanılabileceğini ekonomik materyallerle eğitim yapılabileceğini belirtmiştir. Bu bağlamda sınıf öğretmenlerin STEM eğitimi uygulamaları için malzemelere intiyaç duydukları bu da STEM Eğitimini ekonomik bir eğitim olarak bulmadıkları sonucunu göstermektir. Bu durumun nedeni öğretmenlerin STEM uygulamalarında disiplinleri entegre etmelerindeki zorlanmamalarından da kaynaklanabilir. Bu araștırmanın bir diğer sonucu da öğretmenlerin özellikle mühendislik disiplini STEM eğitimlerine dahil etmede zorlandıklarıdır. Bu duruma ilişkin Stohlman Moore ve Roehring (2012) öğretmenlerin ürün olușturma açısından mühendislik disiplini boyutunda sorun yaşadığını bu durumun alan bilgisi yetersizliğinden kaynaklandığını ifade etmişlerdir. Farklı disiplinleri içinde barındıran STEM Eğitimi farklı alanlar konusunda bilgi sahibi olmayı gerektirmektedir. Bu sebeple öğretmenlerin tüm disiplinlerdeki alan bilgilerini de geliştirecek uygulamalı eğitimlere intiyaç duyulduğu söylenebilir. Araştırmanın sonuçlarıyla benzer paralellikte Yıldırım ve Türk (2018) STEM uygulamalarında STEM disiplinlerinin hepsinin kullanılması gerektiğini ve öğretmenlerin bu alanlar hakkında bilgi sahibi olmaları gerektiğini ifade etmişlerdir. Özbilen (2018) ise öğretmenlerin STEM disiplinlerinden en çok mühendislik bilgisi açısından yetersiz olduklarını bu alanla ilgili eğitime intiyaç duyduklarını belirtmiştir. Bu Araştırmadaki sınıf öğretmenlerinin de STEM uygulamaları için Mühendislik alanında kendilerini yetersiz bulduklarını belirtmeleri literatürle benzerlik göstermektedir.

STEM eğitimini uygulayan sınıf öğretmenlerinin araştırmada STEM eğitimi almanın önemini vurguladıkları görülmüştür. Öğretmenler eğitim almadan etkili uygulamalar yapılmasının mümkün olmadığını STEM eğitimleriyle ilgili öğretmenlerin desteklenmelerini istedikleri sonuçlarına ulaşılmıștır. Öğretmenler mühendislik disiplini konusunda uzman olmadıklarını aldıkları eğitimlerin özellikle bu noktada etkisi olduğunu araştırmada belirtmişlerdir. Harris ve Felix (2010) 'e göre de öğretmenlerin STEM disiplinleri entegrasyonu için eğitim almaları bir gerekliliktir. Ayrıca araştırmada öğretmenlerin eğitim almalarına rağmen kendilerini STEM uygulamaları açısından yetersiz hissettiklerini ifade ettikleri tekrar eğitim alacaklarını belirttikleri aldıkları eğitimleri nitelikleri açısından sorguladıklarını göstermektedir. Araştırmada öğretmenler STEM eğitimlerinin çok çeşitlik gösterdiklerini, bütçelerine uygun olan eğitime dâhil olduklarını belirtmişlerdir. Bircan, Köksal ve Cımbız (2019) da yapmış oldukları araştırmada benzer biçimde Türkiye genelinde eğitim vermekte olan STEM merkezlerinin ortak bir içerikte eğitim vermediklerini belirtmiștir. Bu noktada Verilen eğitimlerin standart bir genel içeriğe sahip olmaları sağlanarak bir kontrol mekanizması oluşturulmasının faydalı olacağı düşünülmektedir.

Bu araştırma kapsamında STEM eğitimi almış Sınıf öğretmenlerinin STEM eğitimine ilişkin görüşleri belirlenmiştir. Sınıf öğretmenlerinin STEM eğitimi uygulamalarındaki intiyaçları dikkate alındığında sınıf öğretmeni adayları için lisans programlarına STEM eğitimine yönelik teorik ve uygulamalı dersler eklenerek bu alanda yeterlilik kazanmaları sağlanabilir. Sını öğretmeni adaylarıyla ile deneysel modelde araștırmalar gerçekleștirilerek STEM Eğitim programları geliştirilmeli eğitim süreçleri boyunca etkilerinin belirlenebileceği araştırmalar gerçekleștirilebilir. $\mathrm{Bu}$ araştırma yedi sınıf öğretmeni ile tek veri toplama aracı üzerinden gerçekleștirilmiștir. Katılımcı sayısı artırılarak veri toplama araçları çeşitlendirilerek yapılacak araştırmalar alan yazına katkı sağlayacaktır.

\section{Kaynakça}

Akgündüz, D., Aydeniz, M., Çakmakçı, G., Çavaş, B., Çorlu, M. S., Öner, T. ve Özdemir, S. (2015). STEM eğitimi Türkiye raporu. İstanbul: Scala Basım.

Anagün, Ş., Atalay, N., Kılıç, Z. ve Yaşar, S. (2016). Öğretmen adaylarına yönelik 21.yüzyıl becerileri yeterlilik algıları ölçeğinin geliştirilmesi: .. Geçerlilik ve güvenirlik çalışması. Pamukkale Üniversitesi Eğitim Fakültesi Dergisi, 40, 160-175. http://dx.doi.org/10.9779/ PUJE768

Aydın, E., \& Karslı Baydere, F. (2019). 7th grade students' views about STEM activities: Example of separation of mixtures. Ondokuz Mayıs University Journal of Education Faculty, 38(1), 35-52.

Başpınar, A. ve Hacıoğlu, B. (2020). Bir sınıf öğretmeni ve öğrencilerinin ilk STEM eğitimi deneyimleri. Karadeniz Sosyal Bilimler Dergisi, 12(22), 1-23. https://doi. org/10.38155/ksbd.690919 
Benuzzi, S. (2015). Preparing future elementary teachers with a STEM-rich, clinical, co-teaching model of student teaching (Doctoral dissertation). California State University, Long Beach.

Bircan, M. A., Köksal, C.., \& Cımbız, A. T. (2019). Examining the STEM centres in Turkey and STEM centre model proposal. Kastamonu Education Journal, 27(3), 10331045. https://doi.org/10.24106/kefdergi.2537

Bozkurt Altan, E., Yamak, H. ve Buluş Kırıkkaya, E. (2016). FeTeMM eğitim yaklaşımının öğretmen eğitiminde uygulanmasına yönelik bir öneri: Tasarım temelli fen eğitimi. Trakya Üniversitesi Eğitim Fakültesi Dergisi, 6(2), 212-232.

Bybee, R. W. (2013). The case for STEM education: Challenges and opportunities. USA:NSTA press.

Ceylan, S. (2014). Ortaokul fen bilimleri dersindeki asitler ve bazlar konusunda fen, teknoloji, mühendislik ve matematik (FeTeMM) yaklaşımı ile öğretim tasarımı hazırlanmasına yönelik bir çalışma (Yüksek lisans tezi). Uludağ Üniversitesi, Bursa.

Çengel, M., Alkan, A., ve Yildiz, E. P. (2019). Evaluate the Attitudes of the Pre-Service Teachers towards STEM and STEM's Sub Dimensions. International Journal of Higher Education, 8(3), 257-267.

Çorlu, M. S. (2014). FeTeMM eğitimi makale çağrı mektubu. Turkish Journal of Education, 3(1), 4-10. https://doi. org/10.19128/turje.181071

Çorlu, M. S., Capraro, R. M., \& Capraro, M. M. (2014). Introducing STEM education: Implications for educating our teachers in the age of innovation. Eğitim ve Bilim, 39(171), 74-85.

Daymaz, B.(2019). Bilim, teknoloji, mühendislik ve matematik (STEM) etkinliklerinin 7. sınıf öğrencilerinin matematik başarı, motivasyon ve STEM kariyer alanlarına etkisi (Yüksek lisans tezi). Kocaeli Üniversitesi, Koceli.

Drake, S. M. \& Burns, R. C. (2004). Meeting standards through integrated curriculum. Virginia, USA: ASCD.

Dugger, W. E. (2010). Evolution of STEM in the United States. Paper presented at the 6th Biennial International Conference on Technology Education Research.Gold Coast, Queensland, Australia.

Eroğlu, S. ve Bektaş, O. (2016). STEM eğitimi almış fen bilimleri öğretmenlerinin STEM temelli ders etkinlikleri hakkındaki görüşleri. Eğitimde Nitel Araştırmalar Dergisi, 4(3), 43-67. https://doi.org/10.14689/ issn.2148-2624.1.4c3s3m

Gonzalez, H. B., \& Kuenzi, J. J. (2012). Science, technology, engineering, and mathematics (STEM) education: A primer. Washington, DC: Congressional Research Service, Library of Congress.

Gülhan, F. ve Şahin, F. (2018). STEAM (STEM+ Sanat) etkinliklerinin 7. sınıf öğrencilerinin akademik başarı, STEAM tutum ve bilimsel yaratıcılıklarına etkisi. Journal of Human Sciences, 15(3), 1675-1699. https:// doi.org/10.14687/jhs.v15i3.5430
Gülpınar, Ş. (2019) Fen bilimleri öğretmenleri ve öğretmen adaylarının STEM'e yönelik farkındalık, tutum ve görüşlerinin belirlenmesi (Yüksek lisans tezi). Mehmet Akif Ersoy Üniversitesi, Burdur.

Harris, J. \& Felix, A. (2010). A project-based, STEM-integrated alternative energy team challenge for teachers. Technology and Engineering Teacher, 69(5), 29-34.

Karataș, F. Ö. (2017). Eğitimde geleneksel anlayıșa yeni bir s(i) tem. Çepni, S. (Eds.), Kuramdan uygulamaya STEM+A eğitimi (s.53-65). Ankara: Pegem Akademi.

Kağınıcı, A. (2019). STEM etkinlikleriyle zenginleștirilmis öğrenme modelinin 11.sınıf öğrencilerinin akademik başarısına ve öğrenme anlayışlarına etkisi (Yüksek lisans tezi). Karamanoğlu Mehmetbey Üniversitesi, Karaman.

Kavacık, i. (2019). Fen, teknoloji, mühendislik ve matematik (Stem) uygulamalarının; Öğrencilerin öğrenme yaklaşımlarına, sorgulayıcı öğrenme becerisi algılarına ve Stem'e yönelik tutumlarına etkisi (Yüksek lisans tezi) Mersin Üniversitesi, Mersin.

Kaya, G. (2019). Fen bilimleri öğretmenlerinin ve öğretmen adaylarının STEM hakkındaki görüşleri ve STEM uygulamalarına yönelik ihtiyaç analizi (Yüksek lisans tezi). Uludağ Üniversitesi, Bursa.

Knight, M., \& Cunningham, C. (2004). Draw an engineer test (DAET): Development of a tool to investigate students ideas about engineers and engineering. Paper presented at the ASEE Annual Conference and Exposition.

Kurtuluş, M., A. (2019). STEM etkinliklerinin öğrencilerin akademik başarılarına, problem çözme becerilerine, bilimsel yaratıcılıklarına, motivasyonlarına ve tutumlarına etkisi (Yüksek lisans tezi). Alanya Alaattin Keykubat Üniversitesi, Antalya.

Küçük, S. ve Șișman, B. (2017). Birebir robotik öğretiminde öğreticilerin deneyimleri. Illköğretim Online, 16(1), 312325. http://dx.doi.org/10.17051/io.2017.12092

Mathison, S., \& Freeman, M. (1998). The logic of interdisciplinary studies. Report Series 2.33. Retrieved from ERIC database (418434).

Meihholdt, C., \& Murray, S. (1999). Why aren't there more women engineers? Journal of Women and Minorities in Science and Engineering, 5(3), 239-263.

Merriam, S. B. (2009). Qualitative research: A guide to design and implementation, revised and expanded from qualitative research and case study applications in education.

Milli Eğitim Bakanlığı. (2016). STEM eğitim raporu. Ankara: Yenilik ve Eğitim Teknolojileri Genel Müdürlüğü.

Morrison, J. (2006). Attributes of STEM education: The student, the school, the classroom. Retrieved from http://Www. tiesteach.org/monographs.aspx.

Olivarez, N. (2012). The impact of a STEM program on academic achievement of eighth grade students in a South Texas middle school (Doctoral dissertation). Loma Linda University, California. 
Özbilen, A. G. (2018). STEM eğitimine yönelik öğretmen görüşleri ve farkındalıkları. Scientific Educational Studies, 2(1), 1-21.

Poyraz, G. (2018). STEM eğitimi uygulamasında Kayseri ili örneğinin incelenmesi ve uzaktan STEM eğitiminin uygulanabilirliği (Yüksek lisans tezi). Erciyes Üniversitesi, Eğitim Bilimleri Enstitüsü, Kayseri.

Sağlam, M., Özüdoğru, O. F. ve Çıray, F. (2011). Avrupa Birliği eğitim politikaları ve Türk Eğitim Sistemi'ne etkileri. Yüzüncü Yıl Üniversitesi Eğitim Fakültesi Dergisi, 8(1), 87-109.

Sahin, A. (2019). The Role of Interdisciplinary Project-Based Learning in Integrated STEM Education. In STEM Education 2.0 (pp. 93-103). Brill Sense.

Siew, N. M., Amir, N., \& Chong, C. L. (2015). The perceptions of pre-service and in-service teachers regarding a project-based STEM approach to teaching science. Springer Plus, 4(8), 1-20.

Stohlmann, M., Moore, T. J. \& Roehrig, G. H. (2012). Considerations for teaching integrated STEM education. Journal of Pre-College Engineering Education Research (J-PEER), 2(1), 28-34. https://doi. org/10.5703/1288284314653

Tezel, Ö. ve Yaman, H. (2017). FeTeMM eğitimine yönelik Türkiye'de yapılan çalışmalardan bir derleme. Eğitim ve Ögretim Araştırmaları Dergisi, 6(1), 135-145.

Turan, K. (2005). Avrupa Birliğine giriş sürecinde Türk-Alman eğitim sistemlerinin karşılaştırılarak değerlendirilmesi. Milli Eğitim Dergisi, 33(167), 173-184.

TÜSIAD. (2017). 30 Mayıs 2020 tarihinde. http://www.tusiad. org/tr/tusiad/temsilcilikler adresinden ulaşıldı.

Yamak, H., Bulut, N. ve Dündar, S. (2014). 5. sınıf öğrencilerinin bilimsel süreç becerileri ile fene karşı tutumlarına FeTeMM etkinliklerinin etkisi. Gazi Üniversitesi Gazi Eğitim Fakültesi Dergisi, 34(2), 249-265.

Yildırım, B. (2016). An Analyses and Meta-Synthesis of Research on STEM Education. Journal of Education and Practice, 7(34), 23-33.

Yıldırım, B. ve Türk, C. (2018). Sınıf öğretmeni adaylarının STEM eğitimine yönelik görüşleri: Uygulamalı bir çalışma. Trakya Eğitim Dergisi, 8(2), 195-213. 